9. Widjaja I, Wang C, van Haperen R, Gutiérrez-Álvarez J, van Dieren B, Okba NMA, et al. Towards a solution to MERS: protective human monoclonal antibodies targeting different domains and functions of the MERS-coronavirus spike glycoprotein. Emerg Microbes Infect. 2019;8:516-30. https:/ / doi.org/10.1080/22221751. 2019.1597644

10. Haagmans BL, van den Brand JM, Raj VS, Volz A, Wohlsein P, Smits SL, et al. An orthopoxvirus-based vaccine reduces virus excretion after MERS-CoV infection in dromedary camels. Science. 2016;351:77-81. https://doi.org/10.1126/science.aad1283

Address for correspondence: Berend-Jan Bosch, Virology Division, Department of Infectious Diseases and Immunology, Faculty of Veterinary Medicine, Utrecht University, Yalelaan 1, 3584 CL, Utrecht, the Netherlands; email: b.j.bosch@uu.nl; Bart L. Haagmans, Department of Viroscience, Erasmus Medical Center, PO Box 2040, 3000 CA, Rotterdam, the Netherlands; email: b.haagmans@erasmusmc.nl

\section{Novel Ehrlichia Strain Infecting Cattle Tick Amblyomma neumanni, Argentina, 2018}

\author{
Lucía Fargnoli, Camilo Fernandez, Lucas D. Monje \\ Author affiliation: Instituto de Ciencias Veterinarias del Litoral, \\ UNL-CONICET, Esperanza, Argentina
}

DOI: https://doi.org/10.3201/eid2605.190940

In 2018, we detected a novel Ehrlichia strain infecting Amblyomma neumanni ticks in Argentina. The novel strain is phylogenetically related to the ruminant pathogen $E$. ruminantium and represents a potential risk for veterinary and public health because $A$. neumanni ticks parasitize domestic and wild ruminants and bite humans.

\title{
etymologia
}

\section{Coronavirus [kə-ro'nə-vi"rus]}

\section{Ronnie Henry}

$\mathrm{T}$ he first coronavirus, avian infectious bronchitis virus, was discovered in 1937 by Fred Beaudette and Charles Hudson. In 1967, June Almeida and David Tyrrell performed electron microscopy on specimens from cultures of viruses known to cause colds in humans and identified particles that resembled avian infectious bronchitis virus. Almeida coined the term "coronavirus," from the Latin corona ("crown"), because the glycoprotein spikes of these viruses created an image similar to a solar corona.

Strains that infect humans generally cause mild symptoms. However, more recently, animal coronaviruses have caused outbreaks of severe respiratory disease in humans, including severe acute respiratory syndrome (SARS), Middle East respiratory syndrome (MERS), and coronavirus disease (COVID-19).

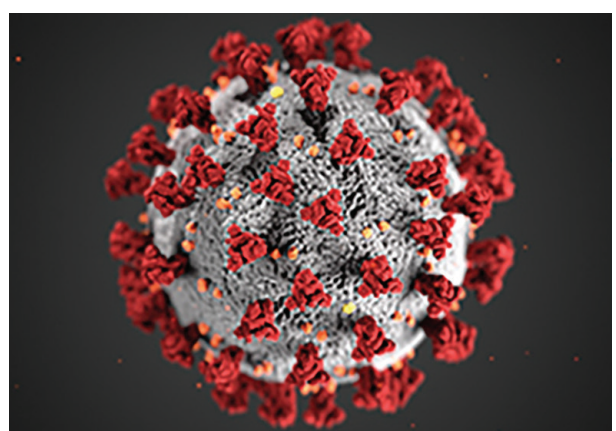

Figure. Illustration reveals the ultrastructural morphology exhibited by coronaviruses. Note the spikes that adorn the outer surface of the virus, which impart the look of a corona surrounding the virion, when viewed electron microscopically. Photo: CDC/ Alissa Eckert, MS; Dan Higgins, MAMS

\section{Sources}

1. Almeida JD, Tyrrell DA. The morphology of three previously uncharacterized human respiratory viruses that grow in organ culture. J Gen Virol. 1967;1:175-8. https://doi.org/10.1099/0022-1317-1-2-175

2. Beaudette FR, Hudson CB. Cultivation of the virus of infectious bronchitis. J Am Vet Med Assoc. 1937;90:51-8.
3. Estola T. Coronaviruses, a new group of animal RNA viruses. Avian Dis. 1970;14:330-6. https://doi.org/10.2307/1588476

4. Groupe V. Demonstration of an interference phenomenon associated with infectious bronchitis virus of chickens. J Bacteriol. 1949;58:23-32. https://doi.org/10.1128/JB.58.1.23-32.1949

Address for correspondence: Ronnie Henry, Centers for Disease Control and Prevention, 1600 Clifton Rd NE, Mailstop V18-2, Atlanta, GA 30329-4027, USA; email: boq3@cdc.gov 
E hrlichia spp. are intracellular gram-negative bacteria relevant to human and animal health; they infect monocytes, neutrophils, or endothelial cells, depending on the species involved (1). The genus Ehrlichia (Rickettsiales: Anaplasmataceae) comprises 6 formally recognized tick-transmitted species: E. canis, E. muris, E. chaffeensis, E. ewingii, E. minasensis, and E. ruminantium $(2,3)$. Recently, other Ehrlichia species have been reported and different strains of putative novel Ehrlichia species have been molecularly detected, but their taxonomic positions are still not clearly defined (4-6). Current knowledge about this group of pathogens suggests that a large number of Ehrlichia species might be not yet described.

Amblyomma neumanni ticks are relevant to human and veterinary medicine because in all stages they commonly parasitize wild and domestic ruminants and other large mammals, including humans (7). Moreover, A. neumanni ticks can reportedly be infected with Rickettsia bellii and Rickettsia amblyommatis and are potential vectors of the cattle pathogen Anaplasma marginale (7). To determine the presence of tickborne bacteria of the genus Ehrlichia in questing A. neumanni ticks in northwestern Argentina, we performed phylogenetic analyses on Anaplasmataceaepositive tick DNA samples. All procedures were approved by the Ethics and Biosafety Committee of the Facultad de Ciencias Veterinarias, Universidad Nacional del Litoral, Esperanza, Argentina.

During May 2018 (late autumn), we collected free-living ticks by dragging and by using dry icebaited traps in Dean Funes $\left(30^{\circ} 22^{\prime} \mathrm{S}, 64^{\circ} 21^{\prime} \mathrm{W}\right)$ and San José de la Dormida $\left(30^{\circ} 21^{\prime} \mathrm{S}, 63^{\circ} 58^{\prime} \mathrm{W}\right)$, Córdoba Province, Argentina. Both sites are located in the Chaco Seco ecoregion. We identified all ticks by using standard taxonomic keys (7) and individually processed them for DNA extraction by using a boiling method (8). We screened DNA extracts for Anaplasmataceae by real-time PCR targeting the $16 \mathrm{~S}$ rRNA gene, as previously described (9). We further tested samples positive for Anaplasmataceae by amplification of Ehrlichia genes $d s b$ and groESL, as described elsewhere (5). We sequenced all amplicons and performed phylogenetic analyses with the maximum-likelihood method.

We collected 229 ticks from Dean Funes (70 adults, 159 nymphs) and 62 from San José de la Dormida (24 adults, 38 nymphs) and identified all ticks as A. neumanni. Only 1 adult tick from San José de la Dormida was positive for Anaplasmataceae by PCR. Further analysis of that sample resulted in 2 sequences of $355 \mathrm{bp}(d s b)$ and $784 \mathrm{bp}$ (groESL). Phylogenetic analysis of the $d s b$ sequence (GenBank accession no. MN176580) showed that the A. neuman$n i$ tick was infected with a species of Ehrlichia, which we named Ehrlichia sp. strain La Dormida, closely related to E. ruminantium (82.0\%, GenBank accession no. CR925677) (Figure, panel A). Other ehrlichiae from South America included in the analysis, such as Ehrlichia sp. strain Córdoba from Argentina (78.0\%, GenBank accession no. KY413807) and Ehrlichia sp. strain Natal from Brazil (79.3\%, GenBank accession no. KY207546), were placed in a clade sister to the group formed by Ehrlichia sp. strain La Dormida and E. ruminantium. Furthermore, the phylogenetic analysis performed by using the groESL sequence (GenBank accession no. MN176581) confirmed these results (Figure, panel B).

Several recent studies conducted in South America reported finding novel ehrlichial agents infecting jaguars, horses, crab-eating foxes, opossums, sloths, and peccaries (6). Unfortunately, only short $d s b$ sequences are available for those ehrlichiae from South America. Phylogenetic analysis including these sequences (210 positions included in the final dataset) placed them all together in a clade sister to the group formed by Ehrlichia sp. strain La Dormida and E. ruminantium (Appendix Figure, https://wwwnc.cdc. gov/EID/article/26/5/19-0940-App1.pdf).

Ehrlichia sp. strain La Dormida, associated with A. neumanni ticks, circulates in rural areas of northwestern Argentina. In our phylogenetic analyses, Ehrlichia sp. strain La Dormida genotype was unique and well separated from all other available ehrlichial sequences, suggesting that it could represent a distinct species yet to be properly characterized. In addition, these analyses positioned Ehrlichia sp. strain La Dormida in a separate group together with E. ruminantium. The species E. ruminantium is native to the Africa continent, where it is the etiologic agent of heartwater, a tickborne disease of major economic relevance with regard to domestic ruminants throughout sub-Saharan Africa (10). Besides E. ruminantium, the only other species of Ehrlichia known to naturally infect and cause clinical manifestations of ehrlichiosis in cattle is E. minasensis (3). However, E. minasensis is phylogenetically distant from E. ruminantium and closely related to E. canis genotypes (3).

We report $A$. neumanni ticks as a potential vector of Ehrlichia sp. strain La Dormida. Because it is assumed that bacteria of the genus Ehrlichia are not transmitted transovarially in ticks (1), infection with Ehrlichia must be acquired during feeding of immature ticks, which then pass the infection to adults by transstadial transmission. Regarding $E$. ruminantium, wild African ruminants are reservoirs 
A

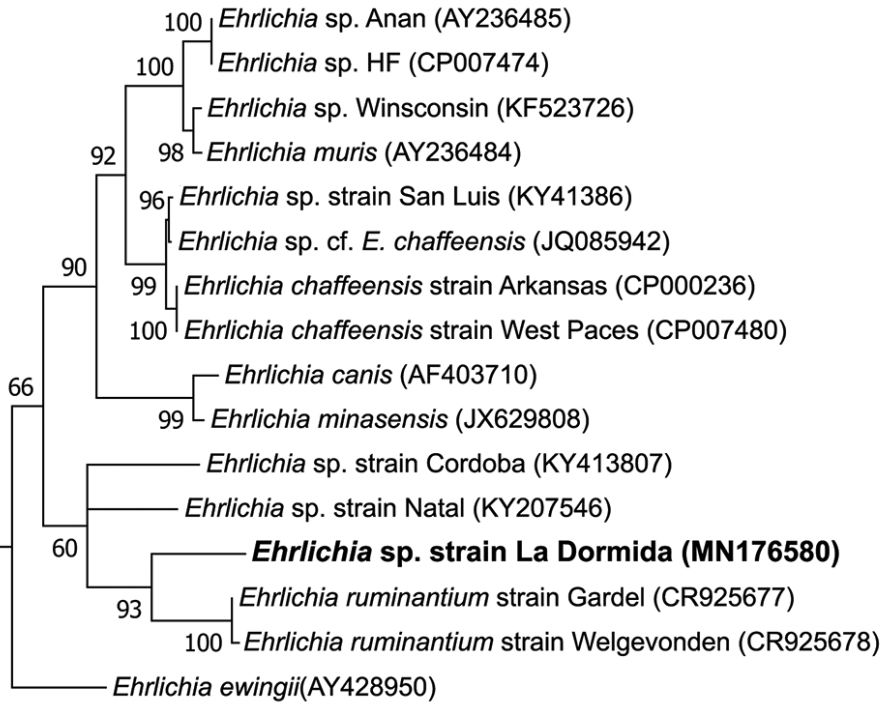

Anaplasma marginale (NC012026)

$\longmapsto .20$

B

99 Ehrlichia cf. E. chaffeensis Marsh deer (JQ085941)

99 Ehrlichia sp. strain San Luis (KY425415)

82 Ehrlichia chaffeensis strain West Paces (CP007480)

91 Ehrlichia sp. Anan (AB032711)

$\begin{aligned} 62 & \text { Ehrlichia sp. NS101 (AB454077) } \\ 98 & \text { Ehrlichia canis strain Mossesane (MG953295) } \\ 9 & \text { Ehrlichia minasensis strain UFMG-EV (JX629806) }\end{aligned}$

$54 \longrightarrow$ Ehrlichia ewingii (AF195273)

57 Ehrlichia sp. Yonaguni 138 (KQ697ichia sp. clone Tajikistan-4 (KJ930194)

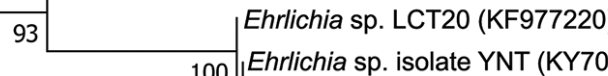

100 Ehrlichia sp. isolate YNT (KY705065)

57 Ehrlichia sp. clone Xinjiang 157-6 (JX402613)

Candidatus Ehrlichia shimanensis (AB074462)

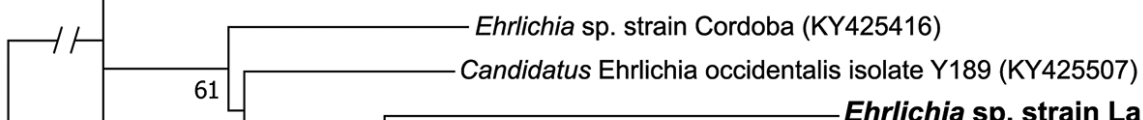

61

Ehrlichia sp. strain La Dormida (MN176581)

78

Ehrlichia ruminantium strain Welgevonden (CR925678)

100 Ehrlichia ruminantium strain Gardel (CR925677)

Candidatus Ehrlichia ornithorhynchi clone PT50 (MF069155)

Ehrlichia risticii (U24396)

Figure. Maximum-likelihood trees constructed from dsb and groESL sequences of Ehrlichia sp. infecting Amblyomma neumanni ticks in Argentina compared with reference strains. A) Tree constructed by using dsb Ehrlichia sequences of approximately the same length as the sequence identified in this study (341 positions included in the final dataset). B) Tree constructed by using groESL Ehrlichia sequences of approximately the same length as the sequence identified in this study (767 positions included in the final dataset). Phylogenetic trees were constructed by using MEGA 7.0 (https://www.megasoftware.net), and best-fitting substitution models were determined with the Akaike Information Criterion, using the maximum-likelihood model test. Numbers represent bootstrap support generated from 1,000 replications. GenBank accession numbers are shown in parentheses. Boldface indicates the strain identified in this study. Scale bars indicate nucleotide substitutions/site. 
of the bacteria (10). The novel Ehrlichia sp. strain La Dormida is phylogenetically related to the ruminant pathogen E. ruminantium and represents a potential risk for veterinary and public health because $A$. neumanni ticks parasitize domestic and wild ruminants and bite humans.

\section{Acknowledgments}

We thank Federico Ruiz and Anibal Gomez for their support with field work and Federico Prandi.

This study was supported by Agencia Nacional de Promoción Científica y Tecnológica (PICT-2015-1084) and Agencia Santafesina de Ciencia, Tecnología e Innovación (IO-2017-00125).

\section{About the Author}

Dr. Fargnoli is a postdoctoral student at the Instituto de Ciencias Veterinarias del Litoral in Esperanza, Santa Fe, Argentina. Her research interests focus on the ecology of tickborne diseases.

\section{References}

1. Brouqui P, Matsumoto K. Bacteriology and phylogeny of Anaplasmataceae. In: Raoul, D, Parola P, editors. Rickettsial diseases. New York; Informa; 2007. p. 179-198.

2. Dumler JS, Barbet AF, Bekker CP, Dasch GA, Palmer GH, Ray SC, et al. Reorganization of genera in the families Rickettsiaceae and Anaplasmataceae in the order Rickettsiales: unification of some species of Ehrlichia with Anaplasma, Cowdria with Ehrlichia and Ehrlichia with Neorickettsia, descriptions of six new species combinations and designation of Ehrlichia equi and 'HGE agent' as subjective synonyms of Ehrlichia phagocytophila. Int J Syst Evol Microbiol. 2001;51:2145-65. https:/ / doi.org/ 10.1099/00207713-51-6-2145

3. Aguiar DM, Ziliani TF, Zhang X, Melo AL, Braga IA, Witter R, et al. A novel Ehrlichia genotype strain distinguished by the TRP36 gene naturally infects cattle in Brazil and causes clinical manifestations associated with ehrlichiosis. Ticks Tick Borne Dis. 2014;5:537-44. https://doi.org/10.1016/j.ttbdis.2014.03.010

4. Eberhardt AT, Fernandez C, Fargnoli L, Beldomenico PM, Monje LD. A putative novel strain of Ehrlichia infecting Amblyomma tigrinum associated with Pampas fox (Lycalopex gymnocercus) in Esteros del Iberá ecoregion, Argentina. Ticks Tick Borne Dis. 2020;11:101318.

5. Cicuttin GL, De Salvo MN, Nava S. Two novel Ehrlichia strains detected in Amblyomma tigrinum ticks associated to dogs in peri-urban areas of Argentina. Comp Immunol Microbiol Infect Dis. 2017;53:40-4. https:// doi.org/10.1016/ j.cimid.2017.07.001

6. Lopes MG, Muñoz-Leal S, de Lima JTR, Fournier GFDSR, Acosta IDCL, Martins TF, et al. Ticks, rickettsial and ehrlichial infection in small mammals from Atlantic forest remnants in northeastern Brazil. Int J Parasitol Parasites Wildl. 2018;7:380-5. https://doi.org/10.1016/j.ijppaw.2018.10.001

7. Nava S, Venzal JM, Gonzalez-Acuña DA, Martins TF, Guglielmone AA, editors. Ticks of the Southern Cone of
America: diagnosis, distribution and hosts with taxonomy, ecology and sanitary importance. London: Elsevier; 2017. p. $135-42$.

8. Monje LD, Costa FB, Colombo VC, Labruna MB, Antoniazzi LR, Gamietea I, et al. Dynamics of exposure to Rickettsia parkeri in cattle in the Paraná River delta, Argentina. J Med Entomol. 2016;53:660-5. https://doi.org/ 10.1093/jme/tjv250

9. Monje LD, Fernandez C, Percara A. Detection of Ehrlichia sp. strain San Luis and Candidatus Rickettsia andeanae in Amblyomma parvum ticks. Ticks Tick Borne Dis. 2019;10: 111-4. https://doi.org/10.1016/j.ttbdis.2018.09.008

10. Allsopp BA. Natural history of Ehrlichia ruminantium. Vet Parasitol. 2010;167:123-35. https://doi.org/10.1016/ j.vetpar.2009.09.014

Address for correspondence: Lucas D. Monje, Laboratorio de Ecología de Enfermedades, Instituto de Ciencias Veterinarias del Litoral, R.P. Kreder 2805, Esperanza, Santa Fe 3080, Argentina; email: lmonje@fcv.unl.edu.ar

\section{Multidrug-Resistant Salmonella Serotype Anatum in Travelers and Seafood from Asia, United States}

\author{
Beth E. Karp, Molly M. Leeper, Jessica C. Chen, \\ Kaitlin A. Tagg, Louise K. Francois Watkins, \\ Cindy R. Friedman \\ Author affiliations: Centers for Disease Control and Prevention, \\ Atlanta, Georgia, USA (B.E. Karp, M.M. Leeper, J.C. Chen, \\ L.K. Francois Watkins, C.R. Friedman); Weems Design Studio, \\ Inc., Suwanee, Georgia, USA (K.A. Tagg)
}

DOI: https://doi.org/10.3201/eid2605.190992

A multidrug-resistant Salmonella enterica serotype Anatum strain reported in Taiwan was isolated in the United States from patients and from seafood imported from Asia. Isolates harbored 11 resistance determinants, including quinolone and inducible cephalosporin resistance genes. Most patients had traveled to Asia. These findings underscore the need for global One Health resistance surveillance.

Aharp increase in Salmonella enterica serotype
Anatum infections reported in Taiwan dur-
ing 2016-2017 was associated with emergence of 